\title{
Correction to: Hunters or farmers? Microbiome characteristics help elucidate the diet composition in an aquatic carnivorous plant
}

Dagmara Sirová ${ }^{1,{ }^{*} \dagger}$, Jiř́ Bárta ${ }^{2 \dagger}$, Karel Šimek $^{1,2}$, Thomas Posch ${ }^{3}$, Jiři Pech $^{2}$, James Stone ${ }^{4,5}$, Jakub Borovec ${ }^{1}$, Lubomír Adamec ${ }^{6}$ and Jaroslav Vrba ${ }^{1,2}$

Correction to: Microbiome (2018) 6:225

https://doi.org/10.1186/s40168-018-0600-7

Following publication of the original article [1], the author reported an error in Fig. 3. The correct Fig. 3 is shown here.

The publishers apologise for this error. The original article [1] has been updated.

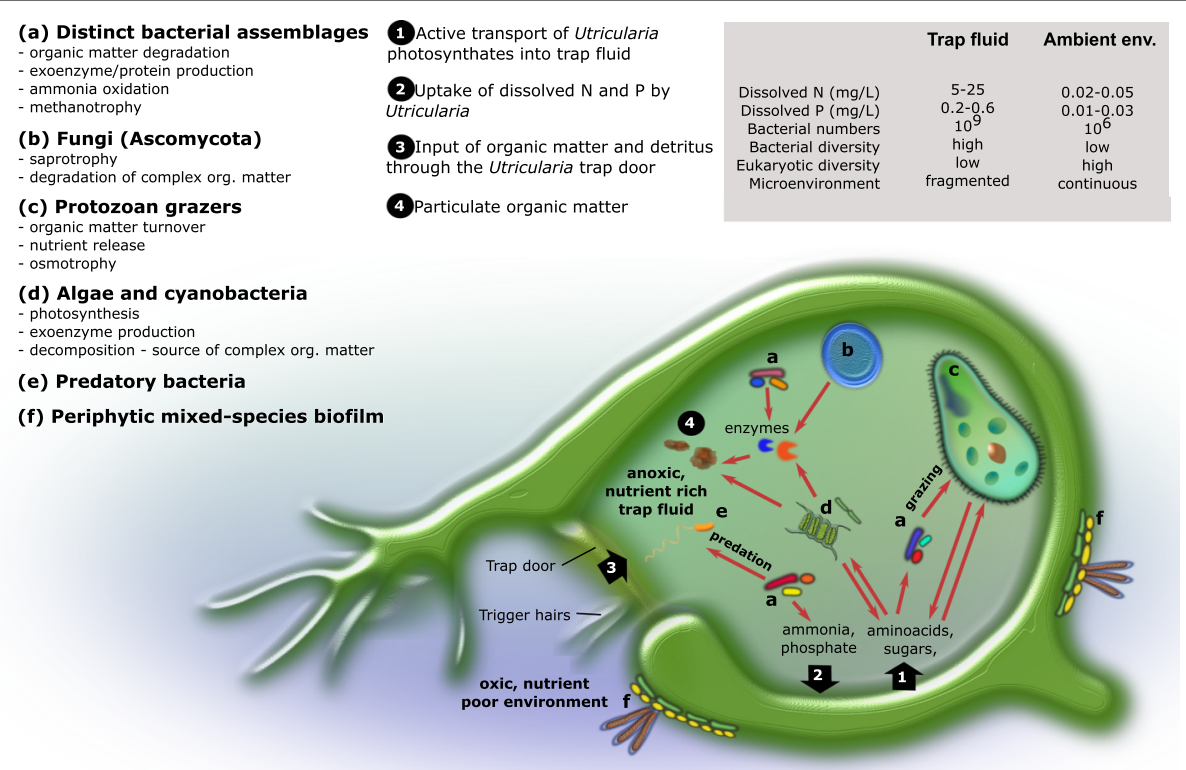

Fig. 3 Conceptual representation of the Utricularia trap ecophysiology: main microbe-microbe and plant-microbe interactions are shown

\footnotetext{
* Correspondence: dagmara_sirova@hotmail.com

${ }^{\dagger}$ Dagmara Sirová and Jiř́ Bárta contributed equally to this work.

'Biology Centre CAS, Institute of Hydrobiology, Na Sádkách 7, CZ-37005

České Budějovice, Czech Republic

${ }^{2}$ Faculty of Science, University of South Bohemia, Branišovská 1760, CZ-37005

České Budějovice, Czech Republic

Full list of author information is available at the end of the article
}

(c) The Author(s). 2019 Open Access This article is distributed under the terms of the Creative Commons Attribution 4.0 International License (http://creativecommons.org/licenses/by/4.0/), which permits unrestricted use, distribution, and reproduction in any medium, provided you give appropriate credit to the original author(s) and the source, provide a link to the Creative Commons license, and indicate if changes were made. The Creative Commons Public Domain Dedication waiver (http://creativecommons.org/publicdomain/zero/1.0/) applies to the data made available in this article, unless otherwise stated. 


\section{Author details}

'Biology Centre CAS, Institute of Hydrobiology, Na Sádkách 7, CZ-37005

České Budějovice, Czech Republic. ${ }^{2}$ Faculty of Science, University of South Bohemia, Branišovská 1760, CZ-37005 České Budějovice, Czech Republic.

${ }^{3}$ Limnological Station, Department of Plant and Microbial Biology, University of Zurich, CH-8802 Kilchberg, Switzerland. ${ }^{4}$ Department of Biology and Wildlife, University of Alaska Fairbanks, Fairbanks AK-99775, USA. ${ }^{5}$ Institute of Experimental Botany CAS, Rozvojová 263, CZ-16502 Praha 6-Lysolaje, Czech Republic. ${ }^{6}$ Institute of Botany CAS, Dukelská 135, CZ-37982 Třeboň, Czech Republic.

Published online: 05 January 2019

\section{Reference}

1. Sirová D, et al. Hunters or farmers? Microbiome characteristics help elucidate the diet composition in an aquatic carnivorous plant. Microbiome. 2018;6(225). https://doi.org/10.1186/s40168-018-0600-7. 